\title{
Arab Women in Israeli Politics: Aspirations for Fundamental Equality or Preservation of Gender Inequality?
}

\author{
Nohad A'li \\ Western Galilee Academic College and University of Haifa, Haifa, Israel \\ Rima’a Da’as \\ AL-Qasemi-Academic College of Education, Israel
}

\begin{abstract}
This paper focuses on reviewing the factors that operate to reduce gender inequality in political representation among Arab women in Israel. A theoretical debate about the changes in the status of Arab women as they are reflected in political representation patterns is conducted in the context of the political reality in the last decade in Israel and the "Arab Spring” events. The paper also focuses on clarifying the significance of the changes in political representation patterns as future trends of reducing gender inequality, within the acknowledged social patterns, which do not subvert the gender order in Arab society in Israel or in the frame of fundamental social change.
\end{abstract}

Keywords: Arab women, gender inequality, political participation, political representation, affirmative action

\section{Introduction}

The issues of women's political representation, affirmative action, and obstructions in their path to integration in local and national politics have attracted much attention in the last decades on the part of academic researchers, civil society organizations, and international organizations (R. Al Maaitah, H. Al Maaitah, Olaimat, \& Gharaeibeh, 2011). The growing interest in different aspects of women's status in society is manifest in academic curriculums focusing on issues of gender and women rights and in the emerging social organizations aiming to promote women’s status in society (Al Maaitah et al., 2011).

Internationally, the concept of women empowerment is an inseparable part of the human rights treaties, which were incorporated in the United Nations Charter (1945) and the Declaration for Human Rights (1948) (New York, USA: NDP, 2009). All the Conventions on the Elimination of All Forms of Discrimination against Women (CEDAW) including Beijing (1995), concentrated on women empowerment and women's rights.

Projects such as the United Nations' Gender Inequality Index (GII), which includes the ongoing collection of data from most countries around the world concerning the characteristics of women in society, indicate the importance attributed to women's status around the world, which itself is an expression of economic development and reduction of social inequality. The UN database includes information such as the rate of women's representation in parliament, educational achievements, and women's participation in the labor market and serves as a foundation for developing political plans to reduce social inequality (Schüler, 2006).

Nohad A'li, Ph.D., Senior Lecturer, Department of Sociology, Western Galilee Academic College and University of Haifa. Rima'a Da'as, Ph.D., Lecturer, Department of Education, AL-Qasemi-Academic college of Education. Correspondence concerning this article should be addressed to Sha'ab Village, P.O. Box 476, Israel. 
However, the increasing prominence of the issue of women's status has not been accompanied by similar change in the political sphere and among decision makers (Saleh, 2006).

Political participation is commonly defined as an activity aimed at affecting the government in one of two ways: (1) by directly affecting policy-makers or implementation of policies; (2) by indirectly affecting the selection of those making these policies (Burns, 2002). Political participation is not limited to elections or government activities, but also includes holding key positions and participating in activities that influence the decision processes that determine individual and community life (Al-Adwan, 2012, p. 137).

Until the 1970s, voting was the sole mode of political expression that women possessed (Sherfman, 1988). The right to vote was granted to women gradually in countries around the world. For example, in New-Zealand the right to vote was granted as early as 1893, in Russia immediately following the Bolshevik revolution in 1917, and in the United States the right to vote was granted women only in 1920, following a modification in the American constitution. A similar process occurred in Central and Western Europe after WWII, and likewise in Japan and South Korea. On the other hand, in part of the Arab Gulf countries the right to vote was granted to women only in the beginning of the 21st century. In Kuwait, for instance, it was granted only in 2005 (Olimat, 2009; Saleh, 2006).

Although Kuwaiti women have been quite successful socio-economically and, since the country's independence, been involved in its development, they have lagged far behind in the political sphere, so much so that they had to endure a prolonged struggle for participation, which resulted in franchising women only in 2005. Yet even this triumph did not lead to any type of electoral success in the past two parliamentary elections. Rivalry, animosity among women, lack of confidence in female candidates, the political culture, and lack of coalition-building with existing political forces are some of the structural factors that have prevented women from winning parliamentary seats (Olimat, 2009).

In spite of the fact that women's entrance to universal politics commenced in the 1970s (Sherfman, 1988), women's political representation in parliament is still lower than their proportion in society, even after four decades, so that they constitute only a fifth of parliament members around the world (IPU, 2013), on average. Comparative data of women's representation rate in parliaments around the world show that there is great variability among countries in the rate of representation of women and in the patterns of change of this rate, which are unrelated to regime type or level of economic financial development. Thus, for example, the rate of political representation of women in three of the most developed Western countries in Europe is lower than one third the number of parliament members. Germany is ranked 25th among parliaments around the world with a women's representation rate of 32.9\%; France is ranked 38th with a women's representation rate of $26.9 \%$; and Britain is ranked a lowly 58th, with a women's representation rate of $22.5 \%$. Among the financially developed countries that are not in Europe, the United States is ranked 78th, with a women's representation rate of $17.8 \%$. Russia is ranked 98th in the world with a women's representation rate of $13.6 \%$. We can find a higher rate in less developed countries with undemocratic regimes in East Asia. For instance Communist China is ranked 54th among parliaments in the world, with a women's representation rate of $23.4 \%$, compared with the more financially developed and democratic Japan, which is ranked 124th, with a women's representation rate of only 7.9\% (IPU, 2013).

The Arab world has been unable to avoid the changes in the representation of women in parliaments around the world, particularly after the Arab Spring events, which began in 2010. Thus, for example, after the elections held in May 2012, Algeria ranked 28th in the world with a women's representation rate of 31.6\%, 
which ranks first in the Arab world. Tunisia, where the Arab Spring started, ranks 2nd in the Arab world. Following the elections in Tunisia in October 2011, it ranked 39th in the world with a women's representation rate of $26.7 \%$.

Due to the 1956 reform of the Family Law, the legal and political status of Tunisian women is superior to that of their female counterparts in the region (Sinha, 2011).

Iraq and Sudan are also ranked relatively high in the Arab world, third and fourth respectively - with a women's representation rate in parliament of over $25 \%$. Saudi Arabia, ruled by a monarchical-conservative regime, has also experienced a significant change, which included the designation of 30 women as members of parliament following the Arab Spring, and it is currently ranked 5th in the Arab world and 69th in the world, with a women's representation rate of 20\% (Arabic Network for Human Rights Information, 2013). Some changes have also occurred in the women's representation rate in parliament in the wider Islamic world, such as in Afghanistan, which is ranked 37th in the world, with a women's representation rate in parliament of 27.7\%, and Pakistan, which is ranked 58th with a women's representation rate of $22.5 \%$ (IPU, 2013). In addition to the rise in the representation rate of women in different parliaments around the world, a further indication of the strengthening of the political status of women is reflected in their representation in the highest political positions, such as prime minister or president. As of July 2013, 17 women serve as presidents or Prime ministers (Female World Leaders Currently in Power, 2013). For much of 2014, the number was 22-a high record, 10 prime ministers and 12 Presidents.

Putative explanations of women's marginality in the political domain refer, among other things, to the definition of the political domain as a manly one (Herzog, 1996). Politics is still perceived as "the last fortress of men" as a center of aggressiveness that is inappropriate for women. This, despite the social changes that have taken place, such as the increase in the rate of women's participation in the labor force, along with the development of new family patterns in which both spouses are breadwinners. As a result of women's failure to compete with men in the political sphere and achieve a level of representation equivalent to their proportion in the community, they have withdrawn to well-defined and delimited domains of activity, in which they do not compete with men. It is possible that the increase of representation of women around the world reflects the increasing power of women's organizations and feminist movements in the last decades, which contradicts the preconceived ideas about politics being the sole domain of male activity (Shapira, King, Fridberg, \& Izkovich-Malka, 2013; Sherfman, 1988). Similarly, in Arab countries this increase is a manifestation of a civil revolution against social inequality in its different aspects, including gender inequality; a revolution marked by the active involvement and leadership of women.

This paper focuses on reviewing trends of change regarding the status of women within Arab society in Israel. The paper begins with general theoretical accounts regarding women's patterns of participation in politics. These explanations can apply to Arab society in Israel, since it acts within a space that includes both Western cultural characteristics, originating in Jewish-Israeli society, and traditional characteristics, originating in the Arab-Islamic culture that dominates the Middle-East. The paper will discuss possible explanations of Arab women's patterns of political representation in Israel, referring to the findings of a survey of attitudes concerning affirmative action for Arab women in the local and national politics of Arabs in Israel (The survey was conducted in 2005; A'li \& Gordoni, 2009), and to changes that took place since then in the actual patterns of representation. 


\section{Political Representation of Women-Theoretical Explanations}

Despite the increase in women's representation in political activity in recent years (Shapira et al., 2013) research on women's participation in politics, which is in its initial stages (Abu A'ksa-Dawood, 2002), is still lacking a comprehensive empirically-founded theory that can offer a full explanation of women's political representation being lower than their proportion in society (Abu A'ksa-Dawood, 2002; Baxter \& Lansing, 1981). There are four prominent explanations offered in the research literature: physiological, functional, cultural, and political. The physiological account refers to biological differences between men and women: Features such as aversion to violation, weakness, and delicacy are attributed to women but not to men, and they are considered physiological characteristics that limit women's participation in politics (Sherfman, 1988). The functional account perceives the traditional roles of women as mothers and housewives as making it difficult for women to enter politics (Saleh, 2006; Sherfman, 1988). The cultural explanation focuses on characteristics, such as defining the political domain as a fundamentally manly practice and attributing negative stereotypes to women who practice politics, for example, by attributing arrogance as a feature characterizing female political leaders in Arab society in Israel (Abu-Baker, 1998). The cultural account considers patriarchal culture-in which men are dominant in all domains, particularly in high positions-a central explaining factor of women's underrepresentation. Patriarchal culture is based on discriminatory traditional attitudes that consider women to be inferior to men (Saleh, 2006). The preservation of inequality in women's representation in politics is attributed to the reproduction of the prevailing social inequality between men and women (Abu A'ksa-Dawood, 2002; Herzog, 1994; Kelly \& Boutilier, 1978). The ability to reproduce inequality is grounded in the institutionalization of the distinction between the private sphere and the public sphere and its acceptance as the naturalstate of being (Abu A'ksa-Dawood, 2002). Finally, the political explanation focuses on the male response to women's participation in politics. Men supposedly object to this and therefore place obstacles in the way of the women trying to participate in politics, through implicit and explicit discrimination (Herzog, 2000; Saleh, 2006).

Other factors suggested in the research literature as responsible for restricting women's participation in politics include, for example, the gender inequality attributed to the capitalist regime; the increasing power of right-wing parties in some Western countries; a reversion back to religion and the rise of religious fundamentalism; the marginality of women's status issues in the media; the high rate of illiteracy among women in third world countries; women's unawareness of the significance of their participation in politics as a means for promoting their status; the nature of women's organized activity, which focuses on personal and local interests instead of on the general interests of women; and also financial factors (Saleh, 2006). This underrepresentation of women in politics in traditional cultures is also explained by educational level, since a high level of education serves as a vital resource for women in overcoming the existing barriers in societies that suffer from a traditional gender role division (Hill, 1981).

The explanations presented above are deeply rooted in some sociological theories: socialization theory, feminist theory, and class theory. Sociologists who adopt this approach as an explanation for the low participation of women in politics perceive the family and school as socialization agents that construct the gender division. The social world is perceived as divided into two spheres: the political-public sphere, characterized by belligerence and rationalism, which are features attributed to men; and the domestic sphere, which is the sphere of women, whose social roles are limited to mother and wife. In the socialization process, 
expressed in the professional ambitions nurtured among boys and girls, girls are educated to aspire to occupy only marginal roles, if any, in the political and social domains (Iglitzin, 1974). Accordingly, women who try to move from the private sphere into the public one are confronted with social and psychological barriers (Herzog, 1994). Thus relegating women to the private sphere excludes them from political practice (Abu A'ksa-Dawood, 2002; Herzog, 1994, 1996, 2001).

Feminist researchers consider the patriarchal structure of society to be the main cause of women's underrepresentation in politics (Abu A'ksa-Dawood, 2002; Jerbi, 1996). Patriarchy is defined as the complete political, financial, psychological, social, and ideological relations that grant superiority to men and cement the inferiority of women (Sharabi, 1988; Sharabi, 1992). The phenomenon of patriarchy crosses boundaries of time, place, culture, nationality, and status (Jerbi, 1996). According to this approach, men occupy the higher positions in the hierarchy and dominate most of the political functions, and therefore enjoy a monopoly over power in the social structure. Women, on the other hand, occupy the base of the social pyramid (Ibid).

In addition to the universal arguments of feminist theory, a unique feminist discourse has developed in the Middle East, which assumes that the significance of oppressing women differs according to social-geographical region, and accordingly, the ways of coping that women develop depend on the numerous contexts in which women live (El-Saadaw, 1997, 2000; Motzafi-Haller, in Abu Rabia'a-queder \&Winer-Levi, 2010). Arab female researchers suggest that the ways in which Arab women cope depend on their awareness of the restrictions imposed on them because of their gender and on their willingness to confront these restrictions in order to generate a more just gender system. This literature also examines how women find creative ways to meet their needs and influence their life circumstances within their culture (Abu Rabia'a-Queder \& Winer-Levi, 2010). Class theories use class concepts to describe inequality between men and women in the political domain. The dominance of men is explained by their exclusive control of property and income, and thus the gender disparity in political participation is attributed to the disparity in the ownership of resources (Sacks, 1974).

This paper focuses on the underrepresentation of Arab women in Israeli politics. Israeli Arab culture has been described as a traditional collectivist culture (Smooha, 2010), high power distance and Patriarchal (Al-Haj, 1988, 1989; Eilam, 2002; Kirkman \& Shapiro, 1997; Sagy, Orr, Bar-On, \& Awwad, 2001; A’li, 2014). Arab culture in Israel is influenced by three cultures: global culture; the Israeli-Jewish culture in which it acts; and Arab-Islamic culture, which is dominant in the Middle-East. Here we focus only on the influence of Jewish and Arab cultures on patterns of political participation, since these are the cultures that have the largest influence on determining women's status in Israeli-Arab society.

\section{Political Participation of Women in Israel}

A myth of equality between men and women existed in Jewish society prior to the establishment of the state. The egalitarian character of Israeli society is attributed first of all to the pioneering tradition and the revolutionary-socialist experience of the kibbutz movement. The myth structure was expressed in the idyllic description of women's status in the first waves of immigration and in their participation in the activities of the Hagana (the primary Jewish paramilitary force in Mandatory Palestine) and the Palmach (the Haganah's elite strike force). With the establishment of the state, the fact that Israel was the only country in the world in which obligatory army duty was applied to both genders was emphasized (Bober-Agasi, 1982). The myth reached its peak in 1969, when Golda Meir was elected prime minister, becoming one of the first women in the world to be elected to such a lofty position (Sherfman, 1988). 
Nonetheless, the struggle for equality was atypical field of activity for Jewish women even before the state's establishment. It is true that the ideology that guided the founders of the settler's society was characterized, among other things, by democratic concepts of gender equality, but in actual fact—and even though women joined the pioneering movement, the kibbutz, and the underground groups, participated in "the conquest of labor" and in the reconstitution of Hebraic culture and society-gender equality did not exist. In each of these settings, women were relegated to marginal roles and were forced to struggle for their right to participate as equals. Even the most basic democratic right to elect and be elected was acquired only in the mid-1920s, following the women's political mobilization and a struggle, which began in 1919 (Herzog, 2000; Safran, 2006). Furthermore, the struggle for Jewish women suffrage in the land came up in a period in which women in many countries around the world had already started to achieve success in their struggle for the right to elect and be elected (Safran, 2006). Actually, to this day women in Israel still haven't achieved equal civil status, this despite the formal declaration of equality included in the Proclamation of Independence and the formal declarations emphasizing the issue of gender equality in the state (Raday, 1995).

The inequality in the political representation of women is particularly conspicuous in light of the far-reaching changes that have occurred in the last fifty years, both in the political system in Israel and in the characteristics of women in Israel. The Israeli political system changed from a highly centralistic one to a decentralized system. The decentralization trend is characterized mainly by the primaries method and by the direct election of the prime minister ${ }^{1}$ (Fogel-Bijari, 1998). On the other hand, the sources for recruitment to the political elite have also changed. In this context, the declining power of the kibbutzim and Moshavim movement, the Histadrut (the Israeli labor union), and to a considerable degree the apparatuses of the political parties, is particularly noticeable. New, lengthy paths to the centers of power have been paved, among these we can find the army, yeshivot, local authorities, and white-collar professions.

Two changes that have occurred in the characteristics of women in Israel over the years are particularly relevant to understanding their political representation. The first change is the significant increase in the rate of women joining the salaried labor market. Thus, for example, towards the end of the 20th century, women comprised over $45 \%$ of the civil work force, compared to less than $30 \%$ at the end of the 1960 s. The other change is the significant rise in the educational level of women. Thus, for example, over $50 \%$ of bachelor degrees, over $45 \%$ of master's degrees, and over a third of Ph.D. degrees are held by women. As pointed out in the research literature, all over the democratic world, the increase in the rate of women's participation in the labor market and in women's educational level has also led to an increase in women's political activity and political achievements. The Scandinavian countries stand out in this respect, and recently countries like England and France have joined them (Ibid). In Israel, the aforementioned changes have led to an increase in the political activity of women, but not to an increase in their achievements. An increasing number of women have presented their candidacy in each election cycle, women's activity in institutional and non-institutional organizations such as the peace movements and "the secure peace movement" (Women in Green) has also increased, and numerous women's and feminist organizations have been established. But none of this has led to a significant change in the political representation of women (Ibid). Women's representation in the Knesset and government is still low, relative to their proportion in society, and religious and Arabic women are totally absent from the political leadership. Since the establishment of the state and until the 14th Knesset (elected in

${ }^{1}$ The direct election of the prime minister was cancelled in 2001. 
1996), the number of women in Knesset was low and ranged between 8 to 11 women in each session, constituting between $6.6 \%$ and $9.1 \%$ of Knesset members. Women's representation in the 14th Knesset decreased slightly and rose once again in the 15th Knesset (elected in 1999) when 15 women were elected, and their rate reached $13.4 \%$, exceeding $10 \%$ for the first time; 18 women were elected to the 16 th Knesset (elected in 2003), constituting 15\% of the Knesset members, and three of them served as ministers; 17 women were elected to the 17th Knesset (elected in 2006), constituting 14\% of the total Knesset members. Two women were appointed as ministers, and a woman served as the chairman of the Knesset (Neker, 2006). In the 18th Knesset, elected in 2009, there was a considerable increase in the number of women elected as 21 women- $17.5 \%$ of the Knesset members and 24 women after the resignation of serving Knesset members. In addition, in that year Hanin Zo'bi-representative of the National Democratic Assembly (BALAD) party—became the first Arab woman elected to serve as a Knesset member on behalf of an Arab party. In the elections for the 19th Knesset in 2013, there was an additional increase in the representation of women, which was manifested in a record number of 27 women in the Knesset (Shapira et al., 2013), which consist 22.5\% of all Knesset members. Women rate in this Knesset is the highest up to day. This increase in Knesset female members raised Israel from the 70th place in women serving in parliaments to the 57 th place in the world ${ }^{2}$.

The record of women number serving as Knesset member, which was set in the 19th-Knesset elections (27 female Knesset members), was broken, and after Yae’l Cohen-Faren joined, the number of female Knesset members exceeded one quarter of the total members for the first time- 32 female Knesset members. In the 20th Knesset, which composition was set in the Knesset elections held in 17 March 2015, 32 female members were elected (consisting 27\% of the total 120 Knesset members), of them only two Arab Knesset members (Mrs Hanin Zoabi and Mrs Aieda Tuma-Suleman) and consist only 12.5\% of the total Arab Knesset members (16 members).

To date, most theories dealing with women's participation in politics focused mainly on national politics, which is expressed in women's participation in governments and parliaments. A smaller number of researches have referred to women's participation in local governance. Herzog (1994) distinguishes between local governance and national governance with regards to women. Women are linked to the local government in two ways: employment and reception of services. Women are employed in the local government, since its fields of activity overlap to a large degree the fields perceived to be feminine. In addition, women are the main consumers of the services that the local government provides. In spite of this, women have not fared any better in the municipal field. In the local government elections held in 2003, only two women were elected to head their local council-in Herzliya and Netanya. In the same elections, 207 women were elected as local council members, constituting a women's participation rate of $10.3 \%$ of all elected council members. Women in Jewish councils made up $14 \%$ of all council members, compared to a mere $0.5 \%$ in the Arab local councils. Women were elected council members in 87 out of 158 local governments (in 55\% of all local governments in which elections were held-in $82 \%$ of all Jewish councils and in $4 \%$ of all Arab councils). This means that in the beginning of the 21 st century, in $45 \%$ of the local councils, no women served at all as council members. In addition, from the establishment of the state up to the beginning of the 21st century, only nine women ever served as mayors of a local government (Neker, 2006). Thus, for example, a comparison between the results of the local government elections in 1998 and the results of those held in 2003 reveals that there were no

${ }^{2}$ http://main.knesset.gov.il/About/History/Pages/WomenInKnesset.aspx. 
significant changes in the level of political representation of women (Zarkor, 2004).

According to a survey conducted on behalf of the UN, Israel ranks low on the scale of women's political representation (in the fourth quintile of countries), in contrast to its high ranking in per capita economic production and in the rate of women's participation in secondary education (in the upper quintile of countries). The survey findings point to a relation between security expenditures and women's representation rate in politics: the higher the level of security expenditures as a percentage of the gross national product, the lower the rate of women's representation in parliament and government. According to these data, Neker (2006) concludes that the education system in Israel provides women with tools that can be translated into higher representation in politics and government, while the financial and security-military systems operate in the opposite direction.

The suggested explanations for women's underrepresentation in Israeli politics refer to characteristics, such as male dominance of positions of power; the status of Judaism in Israel as a factor that cements women's inferiority and low status in society; characteristics of military service, in which $90 \%$ of the senior positions are inaccessible to women; and the security situation and the Israeli-Palestinian conflict, which marginalize the feminist agenda in politics (Hazan, 1995; Herzog, 1996). These explanations view the method of government as beneficial to the powerful groups in society, namely, to men. These explanations are accompanied by additional explanations that are no less convincing, such as the numerous problems facing women who aspire to reach high political positions, which include limited access to financial resources compared to those available to men; less free time for political activity, since women work for pay in the labor market, but also work an additional job at home without pay; the media's indifference to women - unless as victims of male violence-and more. Sometimes good old-fashioned arguments are added to these explanations, reminding us-maybe as an explanation, maybe as justification—that "feminine nature", "socialization", and "education" do not prepare women for the political world (Pogel-Bijawi, 1998). As mentioned, the inferiority of women's status in Judaism also constitutes an explanation of the underrepresentation of women in Israeli politics. A considerable part of the 613 commandments addresses the two genders differently, mainly referring to women as being passive. According to Orthodox Judaism, a woman cannot be a member of a prayer quorum (minyan) nor are women halachically fit to conduct various, fundamental religious ceremonies such as Kiddush, Torah reading (in synagogue) or serving as a witness; women cannot be rabbis, kings, or judges. Accordingly, women are not allowed to serve in public or secular governmental roles ${ }^{3}$ (Bober-Agasi, 1982). In this sense of political representation, Israel is still far from the standards of the developed countries; among 34 OECD (Organization for Economic Cooperation and Development) countries, Israel was ranked in 21st in 2013 (Shapira et al., 2013).

The persistence of inequality in the rate of women's political representation, alongside the existing increase in this rate, indicates the need to examine whether the trend of growth in representation reflects the development of a fundamental, ideological equality, which will lead to a stable, continued reduction in gender inequality in society or, rather, a temporary change originating in governmental activity, such as defining quotas for women's representation, which generates artificial change that lacks a stable cultural-social foundation, and therefore does not reflect fundamental social change.

Actually, there are two trends of change contributing to the enhancement of women's status. These trends are expressed in two aspects: values and legislation. Regarding social values, a noticeable change among the

\footnotetext{
${ }^{3}$ Religious prohibitions are validated by law and by laws of matrimony on all women in Israel and not only the religious ones in light of the strong status of the rabbinate establishment and its role in the daily life.
} 
general public is taking shape. Thus, for example, according to the findings of a survey conducted by the women's lobby in Israel, 90\% of the public would like to see more women in politics and management, because their management style is more cooperative and takes into consideration the issue itself. Women are perceived as more personally involved and more committed to the job, and not only as looking out for their own interests (Neker, 2006). The promotion of women's status is also being carried out in legislation. Several affirmative action laws have been promulgated in Israel and around the world in recent decades. Such laws have been enacted in order to guarantee equal opportunities in employment for groups that throughout history have lacked representation in important positions in society (Crosby, 1994). In Israel, for instance, the policy of affirmative action was expressed in measures, such as the establishment of the Authority for the Promotion of Women's Status in March 1998 and the amendment of the Government Companies' Law, requiring appropriate representation for both genders on the director's boards of government companies. Following this amendment, women's representation on director's boards of government companies increased gradually from $6.8 \%$ in 1993 to $36.47 \%$ in 1999. Another legislative measure was the amendment of the Local Governance Law in 2000, requiring local governments to assign a female advisor for women's affairs, tasked with forming a policy for promoting women in local governments.

\section{Women in the Arab World and Political Participation}

Women's political participation level in the Arab world is affected mainly by the political, historical, economic, and cultural characteristics of the Arab world and by the changes occurring in them (Abu-Baker, 1998; Ahmed, 1992; Al Maaitah et al., 2011; Berkovitch \& Moghadam, 1999; Brooks, 1995; Olimat, 2011). The research literature has examined the status of Arab women and their participation in politics in the context of the characteristics of the society in which they act. Society in Arab countries is characterized by a Muslim majority, a mainly rural population, conservatism, and a strong patriarchal regime (Al Maaitah et al., 2011; Hanush-Sruji, 1995). The father stands at the top of the pyramid, and the distribution labor in society is based on age and gender differences - men control women, and adults control those younger than them (Sharabi, 1988). Traditional conservatism has existed for numerous generations and is reflected in all social domains, particularly in the family. Agriculture constitutes the main source of employment and is characterized by traditional work methods (Hanush-Sruji, 1995). In a society with such characteristics, women do not have an independent existence; they always belong to a male-as wives, daughters, and mothers. In other words, women exist as appendices, lacking any independent identity of their own (Barakat, 1985; Barakat, 2000).

Feminist research in the Middle East examines the ways in which women cope with the multiple power structures (political, financial, social, and cultural) that dictate the context of their lives, and describes the ways in which women negotiate with these powers and moderate and reshape the limits of their cultural freedom. Women within Arab cultures share the experience of being subordinated to men: to father, brother, or husband (Abu Rabia’a-Queder \& Winer-Levi, 2010; Badran, 1995).

Many researchers, mainly in the West, attribute to Islam (Islamic religious law), a significant role in establishing women's inferior status in the family and society (Berkovitch \& Moghadam, 1999; Ingrams, 1983).

Del PradoLu (2013) analyzed the dataset "Party Variation in religiosity and women's leadership: A Cross National Perspective, 2008-2010”, provided by the Inter-University Consortium of Political and Social Research. The database included 329 lists of political parties in 26 countries. The analysis examined political 
participation of women in terms of internal party quota, electoral quota for women, percent share of women in decision-making bodies, interaction of percent female leadership with female membership, and percentage of female nominees. Del PradoLu found a relationship between women's political participation and Islam and differences in electoral participation of women in Muslim majority and non-Muslim majority countries, although the coefficient of determination was small, indicating that women's electoral participation is explained by other factors. The share of women nominees on parties' electoral lists for parliament was found to be only $14.1 \%$, in Muslim countries, with fewer women candidates in party lists being related to extremist Islam, and internal quotas for women among political parties numbering less in Muslim countries (16.2\%) than in Muslim majority countries (57.9\%).

Islam, like Judaism, is a total creed, which doesn't separate religion from the state. Religious laws encompass all aspects of Muslim life and discriminate between men and women in the laws of matrimony (Ingram, 1983). Unlike the Western approach, which considers Islam to be the main reason for the inferior status of Arab-Muslim women in society and politics, there is another approach suggesting heterogeneity in women's status. The main claim of this approach is that despite the fact that Islamic religious laws have a strong position in most Muslim countries, there is a degree of variability in women's status and in their degree of participation in public life, expressed in differences between varying areas, such as between villages and towns, and between modern areas and traditional areas. The reason for this variability is that there are different interpretations of the same religious law. Researchers who champion this approach disagree with the stereotypical image of Arab women, which portrays them as passive and weak. Muslim women enjoy varying degrees of freedom in managing the household and the family, and there are women who show interest in the political system and even engage in it (Ginat, 1982). A similar claim but more critical towards the Western approach was suggested by one of the foremost feminist researchers in the Arab world, Fatima El-Marnissi. El-Marnissi was one of the first researchers to excel in the critical study of Muslim sources, which is a field that emphasizes the positive side of Islam with regards to the status of women and distinguishes between Islamic religious laws and its values on one hand, and the formal policies that purport to implement them on the other. This argument was bolstered by the events of 19 February 2013, in which about 150 members of the appointed Shurah council swore allegiance to the Saudi king, including 30 Saudi women. This measure followed a promise made by the Saudi king in April 2011 concerning the appointment of women to the Saudi parliament, and it was supported by the Saudi Council of Religious Leaders, which is headed by the Mufti of Saudi Arabia (Arab Network for Human Rights Information, 2013). This step was perceived as revolutionary in a religious and traditional country such as Saudi Arabia. Actually, as of 2013, 20\% of the members of the Shurah council in Saudi Arabia were women, which is similar to the worldwide average of 20.7\% (IPU, 2013). However, despite the improvement, this ranking still indicates a significant inequality.

Regarding Arab women's representation in the executive branch, in 1990, eight Arab states (Algeria, Comoros, Egypt, Jordan, Mauritania, Sudan, Syria and Tunisia) had one to two female ministers (Al Maaitah, 2004), yet by 2011, most Arab countries had between 2-6 female ministers (Al Maaitah et al., 2011).

In her famous groundbreaking book, Beyond the Veil, El-Marnissi showed that the general tradition of separating men and women that characterizes Arab countries and Islam are implemented to a far greater degree than required by the original intentions of religious law. For example, research of the Quran shows that in the days of the Prophet, women participated in the political-public sphere without veils. The use of veils, which was meant to distinguish the Prophet's women from other women became, in time, a custom and part of the 
cultural norms (Mernissi, 1975, p. 76). Violation of cultural norms, particularly by women, may lead to painful and even destructive outcomes, since women who try to break barriers are removed from the social circle (Lazerg, 1988). Accordingly, women in the Middle East in general, and Arab women in particular, have developed special ways of coping within their own cultures, which do not undermine the main values of culture and tradition (Muge \& Balaghi, 1994). In other words, feminists in the Middle East use tradition itself for promoting the status of women. One of the unique ways of coping used by Arab women involves the Hijab (veil), which is perceived as a symbol of oppression by Western feminists, while in the eyes of Muslim women the veil is considered as an item of attire that allows women to move freely in the public space, symbolizes loyalty to the tradition, and insures their status in patriarchal society (Abu-Odeh, 1993, in Abu Rabia'a-Queder \& Winer-Levi, 2010; Abu Rabia'a-Queder \& Oplatka, 2008). Female leadership can be partially shaped by cultural patterns that may create a feminine style of leadership. One example is the power of female leadership in Bedouin society, which may be attributed to the cultural position of woman in this tribal, Islamic society. Thus, researchers in Israel (Abu Rabia’a-Queder \& Oplatka, 2008) have found that female supervisors—despite the inferiority of women in traditional Bedouin society—view their femininity as an advantage and as effective in minimizing tribal-professional conflict that is characterized by a contradiction between traditional and rational codes and in taking on a social role in the empowerment of Bedouin women in all spheres of life, among other things (Abu Rabia'a-Queder \& Oplatka, 2008).

Zoref characterizes Arab woman leaders-those coping with the new status-quo in the Arab spring era - as young women, mostly single, in their late twenties, educated, holding jobs in the private sector that provide them with financial independence, socially involved and politically active, wearing a Hijab, and taking care to conform to the standards of modesty in their society. The combination of high education, social awareness, political activism, and Islamic-traditional appearance is a mixture that characterizes a significant part of young women in the revolutionary and post-revolutionary era (Zoref, 2011).

The activities of women leaders in the Arab world take place within the existing political setting and as a part of the general willingness of society's members to act for social and political change. There are two prominent, contrasting theses in the research literature examining women's rights in the Arab world. The first suggests that movements of women's liberation in the Arab world are strongly related to women's participation in the struggle for liberating the nation and homeland from occupation. The participation in the struggle for national liberation legitimized the political activity of women and the establishment of women's organizations that struggled for the advancement of women's status (i.e., Al Maaitah et al., 2011). Thus, for example, Mins (1981)—relying on the research of France Venon, who reviewed five years of activity of the Algerian liberation movement - concluded that "the very participation of women in armed struggle will lead them, eventually, to become aware that they are deprived of their rights, which may motivate them to engage in another struggle in order to achieve their liberation. The participation itself in the struggle, without any other goal except for achieving political independence, has the power to generate a change also in perceptions regarding women's status in society” (Ibid, p. 95; see also Hanush-Sruji, 1995, p. 61).

Zoref (2011), who investigated the issue in three countries during the Arab Spring, concluded that we are faced with a feminine model that constitutes a mixture of the authentic - Islamic and the liberal; a model that is well aware of its gender rights. 
The second thesis suggests that the rights granted to women in some Arab countries were later cancelled due to political and religious pressures (Hijab, 1988). Wadi (1984) likened women's status in Arab society to a seismograph of the process of liberation from occupation and deprivation: In periods of political low points and social deprivation in the Arab world, women took an active role in the struggle in the national arena, while activities in the field of promoting women rights were relegated to the margins; on the other hand, in times of lesser social-national deprivation, the discussion of women's status arose once more (Abu-Baker, 1998; Wadi, 1984). Holt (1996) found an expression of this notion among Palestinian women in the occupied territories. She pointed out a regression in the rights and in the level of women's activity after signing the Oslo Accords between Israel and the P.L.O. According to Holt, during the first uprising, women received rights which enabled them to leave the private sphere and enter the public sphere, while after signing the Oslo Accords, social pressure was applied to limit the rights women had achieved (Ibid). Women leaders in the Arab world, including Israeli-Arab women leaders, thus receive contradictory messages from society at-large: On the one hand, they are encouraged to act to change women's status, but on the other, they are asked to limit their activities to specific political and social contexts (Abu-Baker, 1998).

In recent years, an extensive discussion has commenced regarding the issue of underrepresentation of Arab and Muslim women in parliaments in the Arab world, particularly after the events of the Arab Spring. Thus for example, the procedure of appointing 30 women to the Saudi Shurah council received a great deal of interest and a range of responses on the part of supporters, dissenters, and those having reservations. In Saudi Arabia the responses were varied; a part of the Saudi public supported the measure, but conservatives and Salafi religious figures responded with protests and demonstrations near the king's palace ${ }^{4}$, which is an unusual event in the Saudi regime. The appointment moved Saudi Arabia up to the fourth place in the Arab world in women's representation in parliament, according to the data of the international inter-parliament union, as reported in the Arabic Network for human rights information in 21 of February 2013. In Egypt too, there were far-reaching changes in the debate regarding the representation of women in politics. A policy of affirmative action was suggested in this discussion and presented as a magical solution that would increase the political representation rate and subsequently also raise the status of women in society as a whole. The issue of "quotas" was placed on the agenda of many Arab parliaments as a practical solution for the underrepresentation of Arab and Muslim women in parliament (El-Banna, 2007). Thus, for example, in Kuwait, Qatar, and the Palestinian Authority some laws were enacted that secured $15 \%$ to $25 \%$ of the parliament seats for women.

Generally speaking, there is a correlation between the differences in women's participation in public and political life in Arab countries and the portion of educated females, the strength of prevailing cultural and traditional gender norms, and the availability of a supportive environment (Egypt: UNIFEM Arab state regional office, 2004).

\section{Arab Women in Israel and Political Participation}

In recent years, the names of prominent women in Israeli-Arab society have made the headlines. In the political field, after the elections for the 18th Knesset (2009), Haneen Zuabi became the first Arab woman serving as Knesset member on behalf of an Arab party, the National Democratic Alliance (BALAD). Mrs Aieda Tuma-Suleman joined The 20th Knesset at 2015 as a part of the Joint List. Prior to her, there was

\footnotetext{
${ }^{4}$ http://www.radiosawa.com/content/saudi-women-join-advisory-council-first-time/218935.html.
} 
Husniyeh Jbarah, who served between 1999-2003 as a Knesset member on behalf of Merez, and Nadia Helu, who served in the Knesset from 2003 to 2006 on behalf of the Labor Party. In the academic field, the names of Professor Khaula Abu-Baker from the College of Emek Yezreel (2008) and Professor Fadia Naser Abu-Elheja from Tel-Aviv University (2010) were mentioned as the first Arab women to receive the highest academic degree possible from academic institutions in Israel. In the public arena two Arab women were recognized as highly influential in their fields: Nabila Espanioli, director of the A-Tufulah centre in Nazareth (focused on education of preschoolers and empowering women and introducing them into the labor market), was chosen by the Women Deliver organization as one of 100 inspiring people in the world, and G'idaa Rinawi Zuabi, the general manager of Injaz (The Center for Professional Arab Local Governance), was chosen by The Marker Magazine as one of the 100 most influential people in Israel (Editors' Word, 2011).

Similar to the Arab national minority in Israel, Arab women also have a special, if complex, status. On the one hand, they are a part of the Arab nation and its traditional culture; on the other, they are a part of the State of Israel and its Western culture. This uniqueness has created special ways of coping with their condition of political marginality and attempts to change their political status. Abu-Rabia'a-Queder and Winer-Levi (2010) argue that it seems that the unique ways of coping of Palestinian women in Israel reflect traditional power sources, as they are regularly presented in the Middle East feminist discourse, but also power sources derived from their unique national situation. Palestinian women, it is suggested, are in constant negotiations both with Palestinian society and Israeli society, and their ways of coping reflect social and political power structures that are external to Palestinian society. Furthermore, exposure to Israeli society and Western concepts has expanded the repertoire of power sources and coping styles available to Palestinian women. Unlike Jewish women in Israel and Arab women in the Islamic and Arab world, Arab women in Israel received social and political rights without a preliminary struggle. With the establishment of The State of Israel, women were (formally) granted equal political rights with men. But while it is true that Arab women in Israel preceded their sisters in Arab countries in the reception of political rights, their political achievements are significantly inferior to those of Arab women in many Arab countries (Hanush-Sruji, 1995). Their achievements appear to be inferior primarily when compared with those of Israeli-Jewish women. Gender inequality in Israeli-Arab society is prominent mainly in the political arena.

In spite of the changes in the legal status of Arab women, and despite the social legislation and the "equality laws" legislated by the State of Israel, the status of Arab women is still far from that of Arab men. In modern Arab society - and in Israel as well-there is a collision between modernization and the fetters of tradition. Alongside modernization processes, deeply rooted social patterns and traditional values that have endured for generations are very intensely preserved.

A review of the various women's associations operating within the Arab community reveals that the political organization of Arab women in Israel has accelerated only in the past decade. This trend is rooted in the special historical circumstances of the formation of the Arab-Palestinian minority in Israel and the disruption of their national and organizational relations with the Arab world (Abu A'ksa-Dawood, 2002). Abu-Baker, in her historical review of the political participation of Arab-Palestinian in women, suggests that "ignoring the active presence of Arab women in political life in Israel leads us to the false conclusion that the political activity taking place today among Arab women in Israel is a new phenomenon for women” (Abu-Baker, 1998, p. 19; see also Jad, 1991; Jammal, 1985; Kawar, 1996). The activity of women's associations in Palestine prior to 1948 could have presaged a promising future for women's participation in 
politics (Abu-Baker-Dawood, 2002). Activities of Palestinian women's organizations have been documented in Acre and Jerusalem as early as 1904 and 1906. Among the main activities of these women's organization we can find activities for achieving equal rights between men and women and volunteering activities for the benefit of society (Abu-Baker, 1998; Jad, 1991; Jammal, 1985; Kawar, 1996). Unlike Abu-Baker (1998), Abu A'ksa-Dawood (2002) suggests that the activities of women's organization focused mostly on the humane-national field and were centered around humane aid for refugees and not on issues based on "feminist" awareness and on the need to combine actions in the national arena with action in the field of women's rights.

Since the establishment of the State of Israel in 1948, Arab society has been undergoing changes and transformations in almost all life domains (Al-Haj, 1987). Changes occurred especially after the cancellation of the military government in 1966, which facilitated the movement of people and exposed them to the external environment (Espanioly, 1994; Kamp, 1999). In the social and cultural arenas, Arab society experienced a shock, which was conceptualized in the literature as "a society in transition"-from a traditional, agricultural, collective, closed society to a society that experienced proletarianization. In part, this process was a result of land expropriations conducted by the state after the $1948 \mathrm{War}$, and was expressed in a transition of the Arab work force from agricultural work on their land to hired work out of the village, and the development of financial dependence on Jewish society (H'edar, 1991; Rosenfeld, 1962). These changes influenced women and their status in society. The research literature reports a significant decrease in the political activity of Arab-Palestinian women in Israel in the first two decades after the establishment of the state. Abu-A'ksa-Dawood (2002) indicates that a comparison of the political participation of Arab-Palestinian women prior to the establishment of the state with that occurring between 1948-1970 reveals that in the period prior to the state's existence, women were more active politically. After the establishment of the state, the political-social context of life under military government, in which Palestinian society ${ }^{5}$ acted, constituted a main obstacle to the organization of women in the political-public sphere, since in that period the national agenda received obvious priority (Espanioly, 1994).

The 1970s are perceived as marking the rise of women's organization in Israeli-Arab society. The termination of the military government, the results of the Six-Day War, and the social and economic changes that occurred in that period led to new employment opportunities for Arab-Palestinian women. The compulsory education law that was enacted in 1949, almost immediately following the state's establishment, included women and has contributed to the ongoing increase in the educational level of Arab-Palestinian women. This rise in the level of education created a desire to expand the independence of Arab women and increase their ability to determine their status in society in general and in the political arena in particular (Hanush-Sruji, 1995). The women studying in the universities in the 1970s and early 1980s became the nucleus of the women's and political activities in the 1990s. A significant part of the activists who established Arab women's organizations were academics, women activists from HADASH - the Democratic Front for Peace-who rose from within Jewish or Jewish-Arab women's organizations (Abu-A'ksa-Dawood, 2002). Following the events of the El-Aksah Mosque uprising in October 2000, about 150 women gathered on February 23-24 in Nazareth in order to establish a Palestinian women's council, and towards the end of 2002 a decision was taken in the High

\footnotetext{
${ }^{5}$ In the research literature, there is no consensus concerning the conceptualization of Israeli-Arab society. It is defined alternately as Palestinian, Arab, Israeli-Arab, and more. Due to considerations of convenience we mostly used the prevalent conceptualization - "the Arab society" — but we kept for ourselves "the right” to use also the conceptualization "the Palestinian society". This note is relevant also concerning women-“Arab women" or "Palestinian women".
} 
Follow-Up Committee for Arab Citizens of Israel to assign five women as advisors for the promotion of women's status in local government (Ibid).

Only a few field studies have been conducted regarding the political participation of Arab-Palestinian women in Israel, particularly from the Muslim majority group. The research of Hanush-Sruji (1995) was one of the first studies to examine the influence of the modernization process on the political participation of urban Muslim women. She found that the strong affiliation with tradition among Muslims weakened the extent of political participation, particularly among women, and that there is a positive and linear relation between women's modernization level and their extent of political participation. As a result of her research findings, and in light of the slow pace in which Israeli women integrated into existing party institutions and the failure to establish a separate, independent women's party, Hanush-Sruji concluded that in the near future there is not much of a chance for improvement in the political participation of Israeli women in general, and in that of Muslim women in particular (Ibid, pp. 145-154). These factors compelled Israeli-Arab women to use traditional means in order to generate a change in their political struggle. Abu-Baker (1998) suggested that Arab women leaders in Israel who contend for local political leadership usually use a pragmatic way to change their status and try to influence women's status by cooperating with the existing social structure, without shattering the barriers of tradition and without confronting the existing leadership. The pragmatic way is compatible with the experience and ways of coping of women in the Arab world.

AbuA'ksa-Dawood (2002, p. 216) also relates the phenomenon of Palestinian women's marginality in politics to the marginality of Arabs in the state in general. But according to her, there are also other reasons, related to the social and political structure of Arab society, whose influence is as large as that of the marginality of the Arab minority in the state (Ibid). The author points to a contradiction between the declared egalitarian-liberal positions and the gloomy reality of the representation of Arab women in Israeli politics. All Arab parties included in their campaign the ideal of full equality between the genders, and all of them pointed out the need to integrate women within different political levels, but in reality they did almost nothing. The timidity of the ideological parties that advocate gender equality emphasizes, on one hand, the weakness of these parties vis-à-vis the existing traditional system, and on the other hand their opportunism and the fading effect of ideology. AbuA'ksa-Dawood also points out an organizational failure of the Arab feminist movements in Israel, which failed in putting the issue of women's equality in its proper place. In addition, she suggests that religion does not have a negative role in the context of women's status, since in the in-depth interviews that she conducted with Muslim and Christian religious leaders, the interviewees indicated that there is no religious barrier in the way of women's participation in politics and their filling different political roles (Ibid, p. 218). Ghanem and A'li (2005) examined women's participation in local and national politics and pointed out a contradiction between the marginal status of Arab-Palestinian women in Israel and the existing sympathy of the public for incorporating women in politics. Thus, for example, $73.2 \%$ of respondents of a representative survey conducted in the Arab community in Israel expressed a fundamental willingness to vote for a party headed by a woman.

In order to explain the existing gap between the declared support for incorporating women in politics and their actual exclusion from positions at all political levels, the research literature offers several theories. Some of the researchers attribute the gap to the process in which the Palestinian minority in Israel was established and to its marginality in Israeli politics, particularly in the decision makers' circle. This explanation suggests that the continuing national conflict between the State of Israel and its Arab citizens has marginalized the women's 
issue (Abu-Baker, 1998; Amarah, 1998; Bisharah, 1998). Another explanation suggests that the Israeli-Palestinian struggle and confiscation of land influence the gender roles of Palestinian women, their status in their families and communities, their access to education, employment, and health and welfare services, as well as their psychological well-being, so that the experience of patriarchal oppression is frequently perceived as separate and distinguished from national oppression, but actually they are interweaved (Haj-Yahina, 1998; Hasan, 1999; Othman \& Gorkin, 1996 in Abu Rabi’a-Queder \& Winer-Levi, 2010).

Another explanation attributes Arab women's underrepresentation in politics to social-cultural and religious motifs of traditional Palestinian society, which drives women away from the public sphere because it is not yet ready to accept women in "manly" public politics (Hijab, 1988; Manasra, 1993; Mernissi, 1975; Sharabi, 1988). Another explanation refers to the political culture in Israel, which shunts women, whether Jewish or Arab, from the decision-making systems and excludes them from power and political positions (Hazan, 1995; Herzog, 1996). In summary, the different restrictions detailed above have inhibited the political organization of Arab women in Israel, since they have made it difficult for women to act for women or for national goals (Abu A'ksa-Dawood, 2002, p. 42).

\section{Attitudes Towards Affirmative Action and Political Representation Patterns of Arab Women in Politics: Change and Continuation}

In light of the trend of reduction of gender inequality in women's political representation reviewed above, it is important to understand the system of beliefs prevailing in society concerning women's representation in politics and affirmative action aimed to raise the representation rate. This is due to the fact that a fundamental equality and a stable reduction of gender inequality in society throughout time can take place only in a situation in which there is a change in the ideological perceptions towards women's status in society and their political participation patterns. A lack of empirical researches connecting this system of beliefs to actual political representation is noticeable. Accordingly, the ensuing discussion focuses on the findings of a unique research that examined attitudes towards affirmative action for Arab women in politics, on the explaining variables, and on actual representation patterns. A research based on a representative sample of the adult Arab population in Israel conducted in 2005 found that the degree of support for affirmative action to promote leadership activity of Arab women was negatively influenced by beliefs about the utility of actions for promoting political participation apart from the existing system, such as establishing independent women organizations or alternatively, a boycott of the elections by women (A'li \& Gordoni, 2009). This finding is compatible with the tension mentioned in the research literature (Abu-Baker, 1998) regarding the nature of political activity of Arab women, which combines action within the political system for promoting the status of the Arab minority in Israeli society with activities aimed at changing the status of Arab woman within Arab society, that is, undermining the existing gender order in society. A belief about the effectiveness of activities to change the gender order in society by promoting the rate of women's participation in politics requires a developed gender consciousness that is aware of the gender power relations in society and their antecedents. Furthermore, such a belief undermines the system of social justifications that constitutes the foundation of gender inequality and aspires for social change that will be independently led by women. Hence, the finding that the stronger the belief concerning these actions' effectiveness, the lower the degree of support for affirmative action in the research conducted by A'li and Gordoni (2009) is not surprising. Affirmative action is perceived as a process of incorporating women into the existing system, without necessarily undermining its functioning patterns or the 
general gender system in society. Therefore, it is likely that those with developed gender awareness will be less supportive of affirmative action, which actually reproduces women's inferiority in Arab society in general and in the political sphere in particular. Accordingly, like general theoretical accounts focusing on the struggle of minority groups for equality, one can suggest that support for affirmative action is a manifestation of a pragmatic approach of the minority group members, who are focused on the struggle for material equality and acquiring resources without changing the social structure, whereas support for separation is an expression of an ideological approach that tries to bring about structural changes that will lead to fundamental changes (Harbon, Abu-A'sba, \& Abu Nasrah, 2013). An empirical foundation for the argument that there is a perceptual change in Arab society concerning women's status is also found in the research conducted by A'li and Gordoni (2009), according to which there is a positive correlation between the degree of support for affirmative action in order to promote women's leadership activities and gender ideology. The researchers explained the relationship by the existence of a fundamentally egalitarian perception of women in society. Affirmative action is meant to reduce gender inequality, and accordingly support for affirmative action implies an egalitarian perception of the desired status of women in society. The relationship found between gender, age, and religiosity level on the one hand and the degree of support for affirmative action in politics in favor of Arab women on the other, is attributed by A'li and Gordoni (2009) to the character of gender inequality, in which women are the deprived minority striving to implement its rights and to participate in the political-public sphere, at the expense of men who will lose power and control with the reduction of gender inequality in political representation. The positive relationship between support for affirmative action and age is attributed to the political activity patterns that characterized Arab women in the past, in the period in which the nature of political activity did not undermine the patriarchal gender order; rather it comprised integration in the existing political parties. The relationship between the increase in religiosity level and decrease in the degree of support for affirmative action, which was also found in the A'li and Gordoni's study (2009), implies a contradiction between the level of formal declarations regarding women's participation in politics, and resistance in practice to the integration of women in the political sphere, on the part of religious believers. This finding is compatible with Al-Mernissi's critiques regarding the existing interpretation of Islamic religious laws in some countries, which is tendentious and is meant to grant religious legitimacy to the patriarchal structure of society. The normative tendencies documented in the research of A'li and Gordoni (2009) are compatible with the current trend of increase in the political representation of Arab women, which does not undermine the gender system in the Arab society. Accordingly, one can suggest that despite the fact that the change in political representation patterns is a manifestation of the attitudes towards affirmative action measured earlier, possible future trends, such as an increase in the reversion to religion in Arab society, can moderate change and even reverse it, and future trends of change in representation patterns will also focus on activity within the existing gender system and not in an attempt to undermine it. Further research aimed at examining changes in the population's attitudes in light of the constantly shifting reality can increase our understanding of the processes of change that Arab society is experiencing and can indicate possible action-in the field of education for instance - to promote gender equality in Arab society in general and in the political arena in particular.

\section{References}

Abu-A'ksa Dawood, S. (2002). Palestinian women in politics in Israel. (Doctoral dissertation, the Hebrew University Jerusalem, 2002). 
Abu-Baker, H. (1998). In unpaved way: Arab women as political leaders in Israel. Raa'nana: The Center for Studying the Arab Society in Israel (in Hebrew).

Abu-Odeh, L. (1993). Post-colonial feminism and the veil: Thinking the difference. Feminist Review, 43, $26-37$.

Abu-Rabia-Queder, S., \& Oplatka, I. (2008). The power of femininity. Exploring the gender and ethnic experiences of Muslim women who accessed supervisory roles in a Bedouin society. Journal of Educational Administration, 46(3), 396-415.

Abu-Rabea’a Queder, S., \& Winer Levi, N. (2010). Palestinian women in Israel: Identities, power relations and coping. Jerusalem and Tel-Aviv: Van Leer Institute and the United Kibbutz Movement.

Ahmed, L. (1992). Women and gender in Islam. New Haven: Yale University Press.

Al-Adwan, A. M. (2012). Jordanian women's political participation: On the verge of Arab spring. Journal of International Women's Studies, 13(5), 137-143.

Al-Haj, M. (1987). Social change and family processes: Arab communities in Shefar-A'm. Boulder, Col.: Westview Press.

Al-Haj, M. (1988). The changing Arab kinship structure: The effect of modernization in an urban community. Economic Development and Cultural Change, 36(2), 237-258.

Al-Haj, M. (1989). Social research on family lifestyles among Arabs in Israel. Journal of Comparative Family Studies, 20(2), 175-195.

A’li, N., \& Gordoni, G. (2009). Arab women in the Israeli politics. In F. A'zayzeh, K. Abu-Baker, R. H. Lazarovitch, \& A. G'anem (Eds.), Arab women in Israel: Present situation and a look at the future (pp. 91-114). Tel-Aviv: Ramot Publishing, Tel-Aviv University.

A'li, N. (2014). Violence and crime in Arab society in Israel: A conspiracy institutional or cultural crime. Haifa: University of Haifa and Aman Center.

Al Maaitah, R. (2004). Women in the Arab World: Partners in the community and on the world stage. A paper presented on Arab women and political participation at The Arab International Women's Forum 3rd Annual AIWF Conference. Cairo, Egypt, 6-9.

Al Maaitah, R., Al Maaitah, H., Olaimat, H., \& Gharaeibeh, M. (2011). Arab women and political development. Journal of International Women's Studies, 12(3), 7-26.

Amarah, M. (1998). The role of the clan in the Arabic politics: Adapting to changing patterns. In A. Rekhes (Ed.), The Arabs in the Israeli politics, dilemmas of identity (pp. 91-98). Tel-Aviv: Tel-Aviv University. (in Hebrew).

Arabic Network for Human Rights Information. (2013). Retrieved December 31, 2013, from http://www.anhri.net/?p=71274

Badran, M. (1995). Feminism, Islam and nation: Gender and the making of modern. Egypt, Princeton, NJ: Princeton University Press.

Barakat, H. (1985). The Arab family and the challenge of social transformation. In E. W. Ferna (Ed.), Women and the family in the Middle East: New voices of change (pp. 27-48). University of Texas Press.

Barakat, H. (2000). The Arab society in the 20th century. Beirut: The research center for Arab unity. (in Arabic).

Baxter, H., \& Lansing, M. (1981). Women and politics: The invisible majority. Michigan: The University of Michigan Press.

Berkovitch, N., \& Moghadam, M. V. (1999). Middle East politics and women's collective action: Challenging the status quo. International Studies in Gender, State and Society, 6(3), 273-291.

Bishara, A. (1998). The felled politic discourse. Ramallah, Muaten: The Palestinian Center for Democracy Research. (in Arabic).

Bober-Agasi, Y. (1982). The position of women in Israel. In D. Israeli and others (women editors), Women in trap: About women situation in Israel (pp. 210-230). Tel-Aviv: The United Kibbutz Movement, Red Line Series (in Hebrew).

Brooks, G. (1995). Nine parts of desire: The hidden world of Islamic women. New York: Anchor Books.

Burns, N. (2002). Gender: Public opinion and political action. In Ira Katznelson \& Helen V. Milne, (2002), Political science: State of the discipline (p. 435). London: W.W. Norton \& Company.

Crosby, J. (1994). Understanding affirmative action. Basic and Applied Social Psychology, 15(1-2), 13-41.

Del PradoLu, S. F. (2013). Women's electoral participation in Muslim majority and non-Mulsim majority countries. Journal of International Women's Studies, 14(3), 137-147.

Eilam, B. (2002). "Passing through" a western-democratic teacher education: The case of Israeli Arab teachers. The Teachers College Record, 104(8), 1656-1701.

El-Banna, M. (2007). (Elcuta) The magic solution to guarantee women representation. Cairo. Kon: Arab Women Activists. (in Arabic).

El-Saadawi, N. (1997). The Nawal El-Saadawi reader. London and New York: Zed Books.

Espanioly, N. (1994). Palestinian women in Israel: Identity in light of the occupation. In T. Mayer (Ed.), Women and the Israeli occupation: The politics of change (pp. 106-120). London: Routledge. 
Female world leaders currently in power. (2013). Retrieved December 31, 2013, from http://www.filibustercartoons.com/charts_rest_female-leaders.php

Fogel-Bijawi, S. (1998). Security ceiling over women heads. Nogah-Feminist Magazine, 13-15, 34. (in Hebrew).

Ghanem, H., \& A'li, N. (2005). Attitudes towards the status and rights of Palestinian women in Israel. Nazareth: Women Against Violence Organization.

Ginat, J. (1982). Women in Muslim rural society: Status and role in family and community. New Brunswick, NJ: Transaction Books.

Haj-Yahia, M. (1998). Beliefs about wife beating among Palestinian women: The influence of their patriarchal ideology. Violence against women, 14(5), 533-558.

Hanush-Sruji, M. (1995). Arab Israeli women in politics. Haifa: Private Publishing. (in Hebrew).

Harbon, A., Abu-Asba, K., \& Abu-Nasra, M. (2013). The Arabic education in Israel: A demand for material resources or a conflict over ideological resources? Israeli Sociology, 12(2), 289-311. (in Hebrew).

Hasan, M. (1999). Politics of the honor: Patriarchy, state and killing women in the name of family honor. In D. Israeli and others (women editors), Kind gender politics (pp. 267-307). Tel-Aviv: The United Kibbutz Movement. (in Hebrew).

Hazan, N. (1995). Women as leaders: Tendencies, obstacles and strategies. In politics is for me indeed_Training for developing public and politic career in Israel. Jerusalem: Women Lobby. (in Hebrew).

H'edar, A. (1991). The Arab population in the Israeli economics. Tel-Aviv: The International Center for Peace in the Middle East. (in Hebrew).

Herzog, H. (1994). Realistic women — Women in the local politics in Israel. Jerusalem: Jerusalem Institute for Studying Israel. (in Hebrew).

Herzog, H. (1996). Identities at crossroads-Arab women in Israel. Haifa: Van Leer.

Herzog, H. (2000). Women in Israel. In Sh. Ahroni \& M. Ahroni (Eds.), Israel, 2000 (pp. 42-44). Miksam, Kfar-Saba. (in Hebrew).

Herzog, H. (2001). Women in politics and politics of women. In D. Israeli, A. Fridman, H. Daha-Kelev, H. Herzog, M. Hasan, H. Navah, \& S. Fogel-Bijawi, Gender kind and politics (pp. 307-357). Tel-Aviv: The United Kibbutz Movement.

Hijab, N. (1988). Woman power: The Arab debate on women at work. Cambridge: Cambridge University Press.

Hill, D. (1981). Political culture and female political representation. Journal of Politics, 43, 159-168.

Holt, M. (1996). Women in contemporary Palestine: Between old conflicts and new realities. Jerusalem: Palestinian Academic Society for the Study of International Affairs.

Iglitzin, L. B. (1974). The making of the apolitical woman: Femininity and sex stereotyping in girls. In J. S. Jaquette (Ed.), Women in politics (pp. 25-34). New York: John Wiley.

Ingrams, D. (1983). The awakened women in Iraq. London: Third World Centre.

IPU (Inter-Parliamentary Union). (2013). Women in national parliaments. Retrieved December 31, 2013, from www.ipu.org/wmn-e/classif/htm

Jad, A. (1991). Development of the political role of the Palestinian woman. In S. H’lifa, R. Kajman, A. Jihad et al. (Eds.), Women issues (pp. 95-107). Nablus: Women Issues Association. (in Arabic).

Jammal, L. (1985). Contributions by Palestinian women to the national struggle for liberation. Washington DC: Middle East Relations.

Jerbi, A. (1996). The double price: The position of women in Israel and serving in the Israeli defense forces. Tel-Aviv: Ramot. (in Hebrew).

Kamp, A. (1999). Language of borders' sights: Territorial borders and establishing a national minority in Israel. Israeli Sociology, 2(1), 319-349. (in Hebrew).

Kawar, A. (1996). Daughters of Palestine: Women of the Palestinian national movement. Albany: State University of New York Press.

Kelly, R. M., \& Boutilier, M. (1978). The making of political woman. Chicago: Nelson Hall.

Lazreg, M. (1988). Feminism and difference: The perils of writing as a woman on women in Algeria. Feminist Studies, 14 , 55-69.

Manasra, N. (1993). Palestinian women between tradition and revolution. In E. Augustin (Ed.), Palestinian women: Identity and experience (pp. 7-21). London \& New Jersey: Zed Books.

Mernissi, F. (1975). Beyond the veil: A male-female dynamics in the modern Muslim society. Cambridge, MA: Schenkman Pub Co.

Mins, j. (1981). The woman in the Arab world. Beirut: Dar Al-a'lm (French). 
Motzafi-Haller, P. (2000). Reading Arab feminist discourse: A Post-colonial challenge to Israeli feminism. International Social Science Review, 2, 63-89.

Muge, F., \& Balaghi, S. (1994). Reconstructing genderin the Middle East: Tradition, identity and power. New York: Columbia University Press.

Neker, Y. (2006). Women in Israel 2001-2006. Jerusalem: The Knesset, the Knesset library, review, 3. (in Hebrew).

Olimat, M. (2009). Women and Politics in Kuwait. Journal of International Women's Studies, 11(2), 199-212.

Olimat, M. (2011). The fourth wave: Revolution and democratization in the Arab Middle East. Journal of International Women's Studies, 12(3), 1-6.

Othman, R., \& Gorkin, M. (1996). Three mothers, three daughters: Palestinian women's stories. Berkeley: University of California Press.

Raday, F. (1995). Equality, religion and multiculturalism: The Israeli case. Israel Yearbook of Human Rights, 25, $193-241$.

Rosenfeld, H. (1962). The Arab village proletariat. New Outlook, 5(3), 7-16.

Sacks, K. (1974). Engles revisited: Women, the organization of production and private property. In M. Rosaldo \& L. Louise (Eds.), Women, culture and society (pp. 207-222). Stanford University Press.

Sagy, S., Orr, E., Bar-On, D., \& Awwad, E. (2001). Individualism and collectivism in two conflicted societies: Comparing Israeli Jewish and Palestinian Arab high school students. Youth \& Society, 33, 3.

Saleh, B. (2006). Women political participation and reaching the position of decision making. The Civilized Dialogue, 8(3), 1483. (in Arabic).

Schüler, D. (2006). The uses and misuses of the gender related development index and gender empowerment measure: A review of the literature. Journal of Human Development, 7(2), 161-181.

Shapira, A., King, A., Fridburg, H., \& Itzkovich-Malkah, R. (2013). Representing women in politics: Israel in a comparative view. Policy Research, 99. Jerusalem: The Israeli Institute for Democracy. (in Hebrew).

Sharabi, H. (1988). Neopatriarchy: A theory of distorted change in Arab society. New York: Oxford University Press.

Sharabi, H. (1992). Patriarchy and the complication of the Arab society retardation. Beirut: The Study Center for Arab Unity. (in Arabic).

Sherfman, D. (1988). Women and politics. Haifa: Tamar.

Sinha, S. (2011). Women's rights: Tunisian women in the workplace. Journal of International Women's Studies, 12(3), 185-200.

Smooha, S. (2010). Arab Jewish relations in Israel. Washington: United States Institute for Peace. Retrieved from http://www. usip. org/sites/default/files/resources/PW67_Arab-Jewish_Relations_in_Israel. pdf

Safran, H. (2006). Refusing to be nice women: The struggle for women right of voting and the beginning of the new feminism. Haifa: Pardes Publishing. (in Hebrew).

United Nations Development Program, Arab Human Development, Report 2009: Challenges to Human Security in the Arab Countries. (New York, USA: UNDP, 2009).

United Nations Development Fund for Women/UNIFEM, Progress of Arab Women. (Egypt: UNIFEM Arab state regional office, 2004).

Wadi, T. (1984). Image of the woman in the modern narrative. Cairo: Dar El-Maa'ref. (in Arabic).

Zarkor. (April 2004). Women in Israel. Information and research center of the Knesset. Retrieved from www.kn.esset.gov.il (in Hebrew).

Zoref, M. (2011). Women in the “Arab spring” revolutions: Is it true that the personal is political? In O’zi Rabi \& Arik Rodinzki (Eds.), Women in the Arab society in Israel. Arab update in Israel. Tel-Aviv, Tel-Aviv University, Conard Adnawar Program for Arab-Jewish Cooperation. (in Hebrew). 